\title{
Lou Gehrig and the ALS split hand
}



Lou Gehrig (1903-1941), the New York Yankees baseball player nicknamed "the Iron Horse," began a streak of 2,130 consecutive games in June 1925 that ended when he developed left leg weakness 14 years later. The ALS split hand refers to preferential wasting of abductor pollicis brevis and first dorsal interosseous muscles, with relative preservation of the lateral abductor digit minimi (A). A photograph of Gehrig (B, right) with teammate "Babe" Ruth (B, left) on display at Yankee Stadium, confirms wasting of his left first dorsal interosseous (C). It developed after initial ipsilateral leg weakness, and this pattern of spread of symptoms to contiguous body regions is typical in ALS. ALS = amyotrophic lateral sclerosis.

Patients diagnosed with the neurodegenerative disorder amyotrophic lateral sclerosis (ALS; also known as Lou Gehrig disease) frequently develop dissociated atrophy of the lateral intrinsic hand muscles (figure, A). ${ }^{1}$ Preferential wasting of abductor pollicis brevis and first dorsal interosseous muscles, with relative preservation of the lateral abductor digit minimi, is termed the ALS split hand. ${ }^{2}$ Differential cortical representation of these muscles, linked to the evolution of an opposable thumb, is one postulated explanation. ${ }^{2}$

\section{Matthew C. Kiernan, MBBS, PhD, DSc, FRACP, Martin R. Turner, MA, MBBS, PhD, FRCP}

From the Sydney Medical School and Brain \& Mind Centre (M.C.K.), University of Sydney, Australia; and Oxford University Nuffield Department of Clinical Neurosciences (M.R.T.), John Radcliffe Hospital, Oxford, UK.

Author contributions: Prof. Turner contributed to concept, design, and revision of the manuscript. Prof. Kiernan contributed to concept, design, and revision of the manuscript.

Study funding: No targeted funding reported.

Disclosure: Martin R. Turner receives funding support from the Medical Research Council \& Motor Neurone Disease Association Lady Edith Wolfson Senior Clinical Fellowship. Matthew C. Kiernan receives funding support from National Health and Medical Research Council of Australia (Forefront Program Grant). He serves as Editor-in-Chief of the Journal of Neurology, Neurosurgery \& Psychiatry (BMJ Publishers). Go to Neurology.org for full disclosures.

Correspondence to Prof. Kiernan: matthew.kiernan@sydney.edu.au

1. Kiernan MC, Vucic S, Cheah BC, Turner MR, Eisen A, Hardiman O. Amyotrophic lateral sclerosis. Lancet 2011;377:942-955.

2. Turner MR, Hardiman O, Benatar M, et al. Controversies and priorities in amyotrophic lateral sclerosis. Lancet Neurol 2013;12: $310-322$. 


\section{Neurology}

\section{Lou Gehrig and the ALS split hand}

Matthew C. Kiernan and Martin R. Turner

Neurology 2015;85;1995

DOI 10.1212/WNL.0000000000002172

This information is current as of November 30, 2015

\section{Updated Information \&} Services

\section{References}

Subspecialty Collections

Permissions \& Licensing

\section{Reprints}

including high resolution figures, can be found at: http://n.neurology.org/content/85/22/1995.full

This article cites 2 articles, 0 of which you can access for free at: http://n.neurology.org/content/85/22/1995.full\#ref-list-1

This article, along with others on similar topics, appears in the following collection(s):

All Clinical Neurology

http://n.neurology.org/cgi/collection/all_clinical_neurology Amyotrophic lateral sclerosis

http://n.neurology.org/cgi/collection/amyotrophic_lateral_sclerosis_

Information about reproducing this article in parts (figures,tables) or in its entirety can be found online at:

http://www.neurology.org/about/about_the_journal\#permissions

Information about ordering reprints can be found online:

http://n.neurology.org/subscribers/advertise

Neurology ${ }^{\circledR}$ is the official journal of the American Academy of Neurology. Published continuously since 1951, it is now a weekly with 48 issues per year. Copyright @ 2015 American Academy of Neurology. All rights reserved. Print ISSN: 0028-3878. Online ISSN: 1526-632X.

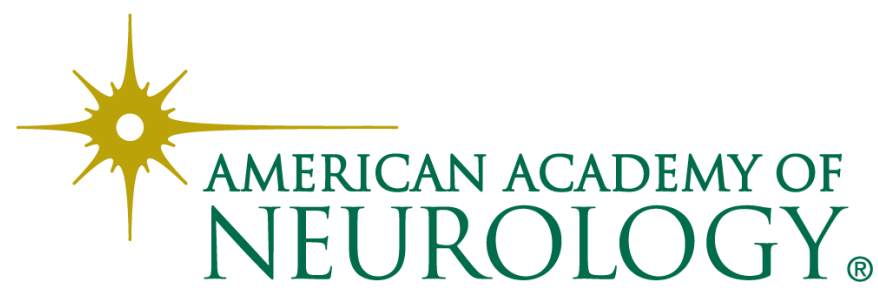

